\title{
Effects of wheat stubble on runoff, infiltration, and erosion of farmland on the Loess Plateau, China, subjected to simulated rainfall
}

\author{
Linhua Wang ${ }^{1}$, Bo Ma ${ }^{1}$, and Faqi Wu ${ }^{1,2}$ \\ ${ }^{1}$ Institute of Soil and Water Conservation, Northwest A\&F University, Yangling 712100, China \\ ${ }^{2}$ College of Natural Resources and Environment, Northwest A\&F University, Yangling 712100, China \\ Correspondence to: Faqi Wu (wufaqi@263.net)
}

Received: 28 November 2016 - Discussion started: 7 December 2016

Revised: 16 February 2017 - Accepted: 22 February 2017 - Published: 8 March 2017

\begin{abstract}
Soil and water losses in agriculture are major environmental problems worldwide, especially on the Loess Plateau, China. Summer fallow management may help to control soil erosion and conserve water. This study investigated the effects of wheat stubble on runoff, infiltration, and soil loss in laboratory plots under simulated rainfall. The treatments comprised wheat stubble cover (WS) and traditional plowing (TP) in runoff plots $(4.0 \mathrm{~m} \times 1.0 \mathrm{~m})$ with three slope gradients $\left(5,10\right.$, and $\left.15^{\circ}\right)$ under simulated rainfall at $80 \mathrm{~mm} \mathrm{~h}^{-1}$ for $1 \mathrm{~h}$. The runoff volume from WS plots was significantly less than that from TP. The runoff reduction with WS ranged from 91.92 to $92.83 \%$ compared with TP. The runoff rates varied with the runoff volume in the same manner. The infiltration amount was higher with WS (94.8$96.2 \%$ of rainwater infiltrated) than TP $(35.4-57.1 \%)$. The sediment concentration was significantly lower with WS than TP. Compared with TP (304.31-731.23 $\mathrm{g} \mathrm{m}^{-2}$ ), the sediment losses were reduced dramatically in WS $\left(2.41-3.78 \mathrm{~g} \mathrm{~m}^{-2}\right.$ ) and the sediment loss slightly increased with slope; however, it was greatly increased as slope increased in TP. These results revealed that the stubble cover was the main factor reducing runoff and sediment losses and improving infiltration and that stubble showed a great potential to control erosion and conserve soil and water resources during the summer fallow period in the Loess Plateau region.
\end{abstract}

\section{Introduction}

Soil and water losses from agricultural land, particularly sloped farmland, are regarded as major environmental threats to ecosystem sustainability on the Loess Plateau, China. Approximately $60 \%$ of the total watershed sediment and runoff is derived from sloped farmland due to natural and human factors, such as the precipitation intensity, geomorphology, and soil management practices, which all contribute to farmland degradation (Keesstra et al., 2016; Liu et al., 2012; Nishigaki et al., 2017b; Zhao et al., 2017; Ziadat and Taimeh, 2013).

The susceptibility to soil and water losses is higher on farmland than land with other vegetation types (e.g., forestry, shrub, and grass) (Boardman et al., 1990; Shi and Shao, 2000; Tang, 2004). This is because the characteristics of crops, including the crop canopy architecture and root system, differ from those of other vegetation types, which leads to severe soil erosion on farmland (Cerdà et al., 2009; Gómez et al., 2004; Llorens and Domingo, 2007). In particular, crops are harvested, which means that there is a fallow period when vegetation does not cover the soil surface. In the Loess Plateau region of China, farmers conduct tillage practices during the summer fallow period after harvesting winter wheat in June. The main aims of summer tillage are removing weeds and creating a favorable rough surface to maximize rainfall capture and minimize soil evaporation (Hammel et al., 1981; Vermang et al., 2015). However, soil management in the summer fallow period may completely disrupt the surface soil, thereby making farmland more susceptible to severe soil erosion in the fallow rainy season (Wang et al., 
2017). In the Loess Plateau region, most of the annual rainfall is concentrated in the summer between July and September, when $60-70 \%$ of the total annual rainfall occurs (Shi and Shao, 2000). Thus, the rainfall is erratic and it occurs with a high intensity and short duration. Summer tillage of bare sloped farmland means that extreme erosive rainfall events can cause severe surface runoff and soil erosion. Thus, the occurrence of rainfall and the tillage of sloped farmland in the summer contribute greatly to extreme soil erosion. This is why soil erosion from sloped farmland is recognized as the main source of sediment losses, which are higher than those from other land use types. Therefore, it is crucial to prevent soil erosion from sloped farmland during the summer fallow period.

To reduce soil erosion from farmland, numerous studies have considered the roles of surface cover and soil management practices in conservation agriculture worldwide (Bescansa et al., 2006; Jordán et al., 2010; Prosdocimi et al., 2016; Swella et al., 2015; Won et al., 2012). Retaining a surface covered with a layer of crop residues is a suitable management practice for preventing soil losses and conserving rainwater on farmland. Thus, Gholami et al. (2013) and Kukal and Sarkar (2010) investigated the effects of straw mulch on soil erosion under laboratory simulated rainfall conditions and concluded that straw mulch was effective in delaying the runoff initiation time as well as reducing splash erosion, runoff, and soil losses. Nishigaki et al. (2017a) investigated the effects of vegetative residues on runoff and soil losses under field experiment conditions; the results showed that surface mulch reduced soil losses caused by raindrop detachment and also suppressed runoff generation. Mwango et al. (2016) studied the effectiveness of mulching on soil erosion and nutrient losses and found that mulches had greater potential in decreasing runoff, soil, and nutrient losses, and similar results were also observed by Wang et al. (2016) in the Jujube plot. Jordán et al. (2010) showed that the application of wheat straw mulch could improve the physical and chemical properties of soil as well as reduce runoff and soil losses in cultivated land. Prosdocimi et al. (2016) examined the effects of straw mulch on soil erodibility and surface runoff and found that straw cover can be effective in reducing soil erodibility, thereby decreasing the soil erosion risk on cultivated land. Similar results were obtained by Cerdà et al. (2016), who found that straw residues were effective in reducing soil and water losses from agricultural land under simulated rainfall in the field. Swella et al. (2015) showed that retaining crop residues increased rainfall infiltration and reduced evaporation during the summer and autumn. Aboudrare et al. (2006) investigated the effects of fallow management on soil water storage during the fallow period in semiarid Mediterranean conditions, where they found that the implementation of appropriate management could maximize the capture of rainwater. Blanco and Lal (2008) investigated tillage practices to increase rainwater storage for winter wheat production and runoff reduction in the dry- land areas of the western USA and Great Plains during the summer fallow periods. Lee and Yang (1965) reported that summer plowing during the summer fallow period can improve the physical, chemical, and biological properties of soil, thereby increasing winter wheat production in the Loess Plateau region. These studies have provided insights into the importance of surface cover and soil management practice for controlling soil and water losses from farmland. Beneficial strategies for soil and water conservation are based on the following principles: providing cover to absorb raindrop kinetic energy as well as reducing splash erosion and the overland flow velocity (Gholami et al., 2013, 2014; Sadeghi et al., 2015); improving the physical and chemical properties of soil, such as the organic matter content and stability of aggregates (Jordán et al., 2010); increasing the soil infiltration capacity and decreasing evaporation (Adekalu et al., 2007; Swella et al., 2015; Todd et al., 1991); and creating a rough surface to decrease runoff and enhance infiltration (Strudley et al., 2008; Vermang et al., 2015; Wang et al., 2017). The obvious advantages of crop residues as a soil cover in conservation agriculture are known, but the effects of crop residues on rainwater capture and soil and water losses from sloped farmland have been studied little, especially during the summer fallow period in the Loess Plateau region.

On the Loess Plateau, the area of cultivated land is $145800 \mathrm{~km}^{2}$, which accounts for $25.6 \%$ of the total land area. About $70 \%$ of the cultivated land comprises rainfed areas, which are distributed across mountainous and hilly regions (NDRC et al., 2002). On sloped farmland, a combination of continuous and intense cultivation, inappropriate soil management, and concentrated rainfall in the summer fallow period has caused severe soil erosion, thereby decreasing the soil productivity and increasing land degradation. Wheat is one of the major crops in the Loess Plateau region, where it accounts about $35 \%$ of the total cultivated area and $30 \%$ of the total crop production (NDRC et al., 2002). The availability and costs of application with stubble cover mean that it is practical for farmers to implement this method in the summer fallow periods. In addition, retaining stubble cover is an efficient and environmentally friendly method that utilizes the crop biomass. The present study aimed to investigate the effects of retaining the stubble from wheat on runoff, erosion, and rainwater capture in a laboratory plot under simulated rainfall and different slope conditions. The results of this study provide a better understanding of the effects of stubble cover for farmers and policy makers, which may be important for conserving soil productivity and supporting sustainable agriculture in the Loess Plateau rainfed area. 


\section{Material and methods}

\subsection{Experimental plots and rainfall simulator}

This study was performed at the Laboratory of Soil and Water Conservation located at the Northwest A\&F University campus, Yangling, Shannxi Province. Yangling $\left(107^{\circ} 59^{\prime}-\right.$ $108^{\circ} 08^{\prime} \mathrm{E}, 34^{\circ} 14^{\prime}-34^{\circ} 20^{\prime} \mathrm{N}$ ) is located on the Guanzhong Plain at an altitude of 516.4-540.1 m. This area has a warm temperate, semi-humid monsoon climate with an average annual temperature of $12.9^{\circ} \mathrm{C}$. The annual precipitation is $635.1 \mathrm{~mm}$, and the highest rainfall occurs in the period from July to September, which accounts for $60-70 \%$ of the annual precipitation. The experiments were conducted on runoff plots built in 2009, as shown in Fig. 1a. The areas of most plots used for laboratory rainfall simulations in previous studies were less than $5 \mathrm{~m}^{2}$ (Huang et al., 2013; Wu et al., 2014; Zhao et al., 2013). In the present study, the runoff plot measured $4.0 \mathrm{~m}$ (length) $\times 1.0 \mathrm{~m}$ (width) $\times 0.6 \mathrm{~m}$ (depth), and four runoff plots comprised a slope gradient group. The slope gradients of the runoff plots were 5, 10, and $15^{\circ}$, which represented farmland with slight, gentle, and steep slopes in the field based on the classification of farmland in the Loess Plateau region, where $42 \%$ of the farmland has slopes of $5-15^{\circ}$ (NDRC et al., 2002). The runoff plots were filled with soil, which was taken from the top 0-20 cm soil layer of a farm in Yangling after the runoff plot was constructed in July 2009. The soil was clay loam and its major physicochemical properties are summarized in Table 1. Before placing the soil in the plot, a $10 \mathrm{~cm}$ layer of sand was laid at the bottom to allow free drainage. After filling with soil, the runoff plots were left for 1 year to allow natural compaction in order to obtain soil properties similar to the natural conditions. Each runoff plot had an aluminum sheet at the lower end of the plot, which served as an outlet for collecting runoff samples.

Rainfall simulation is used widely as a method for studying runoff and erosion processes. The portable rainfall simulation system used in the present study was developed by the Institute of Soil and Water Conservation, Chinese Academy of Science and Ministry of Water Resources, as described by Wang et al. (2017). Its main components comprised a pumping system, inlet pipes, control valve, steel pipes, piezometer, spray nozzles, and a bracket to hold the spray nozzle (Fig. 1b). Raindrops were generated by a spray nozzle with a drop height of $7.5 \mathrm{~m}$ and they had comparable characteristics to natural rainfall in terms of height. Depending on the water supplied by the pump, the rainfall intensity varied according to different pressures displayed on the piezometer, which was installed at the inlet of the steel pipe. The rainfall simulator system was calibrated by the pressure to obtain different intensities. The effective cover area of the simulated rainfall was $5.0 \mathrm{~m}$ in length and $4.0 \mathrm{~m}$ in width, which was sufficient to cover the area of the two runoff plots while avoiding border interference. Therefore, simulated rainfall was applied si-

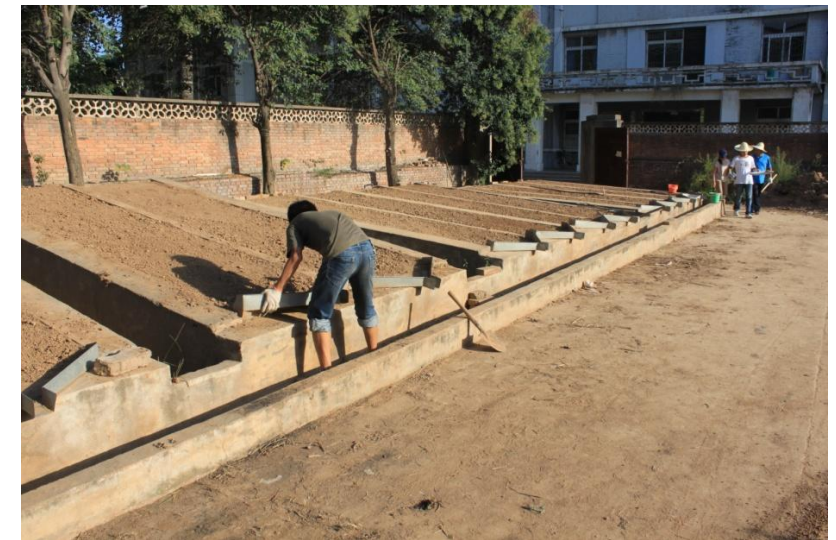

(a)

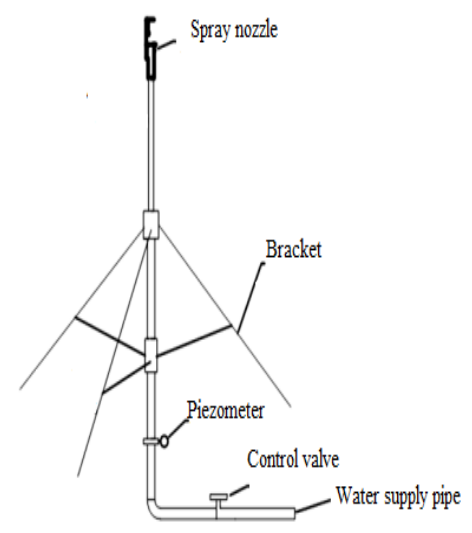

(b)

Figure 1. Experimental runoff plots (a) and schematic of the rainfall simulator (b).

multaneously to two neighboring plots. The two rainfall simulators were placed between neighboring runoff plots. One rainfall simulator was placed $0.5 \mathrm{~m}$ from the upslope plot edge and the other was placed $0.5 \mathrm{~m}$ from the downslope edge. During rainfall simulations, the adjacent plots were covered with plastic sheets to prevent rain falling on the soil.

\subsection{Experimental treatments}

The experiment was conducted in June 2013. The wheat variety used was Xiaoyan-22, and it was sown in four plots during October 2012. Soybean (2010) and maize (2011) had been planted in the plots for scientific research before the plots were planted with wheat. The plots were cleaned, plowed, and prepared to obtain a seedbed, as shown in Fig. 1a. The wheat was sown in rows with a space of $20 \mathrm{~cm}$, and the sowing rate was $13 \mathrm{~g} \mathrm{~m}^{-2}$. During the wheat growth season, the crop management practices were similar to those 
Table 1. Selected chemical and physical properties of the soil.

\begin{tabular}{|c|c|c|c|c|c|c|c|c|c|}
\hline \multirow{2}{*}{$\begin{array}{l}\text { Soil } \\
\text { type }\end{array}$} & \multicolumn{3}{|c|}{ Particle size $\%$} & \multirow{2}{*}{$\begin{array}{l}\text { Soil } \\
\text { texture }\end{array}$} & \multirow{2}{*}{$\begin{array}{l}\text { Organic } \\
\text { matter \% }\end{array}$} & \multirow[b]{2}{*}{$\mathrm{pH}$} & \multirow{2}{*}{$\begin{array}{l}\text { Wet } \\
\text { aggregate } \\
\text { stability } \\
\mathrm{mm}\end{array}$} & \multirow{2}{*}{$\begin{array}{l}\text { CEC (cation } \\
\text { exchange } \\
\text { capacity) } \\
\text { cmol kg }^{-1}\end{array}$} & \multirow{2}{*}{$\begin{array}{l}\mathrm{CaCO}_{3} \\
\mathrm{~g} \mathrm{~kg}^{-1}\end{array}$} \\
\hline & Sand & Silt & Clay & & & & & & \\
\hline Lou soil & 30.0 & 43.7 & 26.3 & clay loam & 1.33 & 8.2 & 1.4 & 18.1 & 74.6 \\
\hline
\end{tabular}

Table 2. The time to runoff initiation, runoff rate, runoff volume, sediment concentration and loss, and cumulative infiltration amount for WS and TP under each condition.

\begin{tabular}{|c|c|c|c|c|c|c|c|}
\hline Slope & Treatment & $\begin{array}{l}\text { Time to } \\
\text { runoff (min) }\end{array}$ & $\begin{array}{l}\text { Runoff rate } \\
\left(\mathrm{mm} \min ^{-1}\right)\end{array}$ & $\begin{array}{l}\text { Runoff } \\
\text { volume (mm) }\end{array}$ & $\begin{array}{l}\text { Sediment } \\
\text { concentration }\left(\mathrm{g} \mathrm{L}^{-1}\right)\end{array}$ & $\begin{array}{l}\text { Sediment } \\
\text { loss }\left(\mathrm{g} \mathrm{m}^{-2}\right)\end{array}$ & $\begin{array}{l}\text { Cumulative } \\
\text { infiltration amount }(\mathrm{mm})\end{array}$ \\
\hline \multirow[t]{2}{*}{5} & WS & $23.68 \pm 4.29^{\mathrm{a}}$ & $0.09 \pm 0.00^{\mathrm{b}}$ & $3.00 \pm 0.51^{b}$ & $0.82 \pm 0.19^{b}$ & $2.41 \pm 0.14^{\mathrm{b}}$ & $76.12 \pm 0.74^{\mathrm{a}}$ \\
\hline & $\mathrm{TP}$ & $4.78 \pm 0.36^{\mathrm{b}}$ & $0.66 \pm 0.01^{\mathrm{a}}$ & $37.86 \pm 0.67^{\mathrm{a}}$ & $8.18 \pm 0.04^{\mathrm{a}}$ & $304.31 \pm 5.93^{\mathrm{a}}$ & $43.90 \pm 1.11^{\mathrm{b}}$ \\
\hline \multirow[t]{2}{*}{10} & WS & $11.26 \pm 2.35^{\mathrm{a}}$ & $0.07 \pm 0.00^{b}$ & $3.39 \pm 0.0 .15^{b}$ & $0.89 \pm 0.17^{b}$ & $3.04 \pm 0.49^{\mathrm{b}}$ & $75.95 \pm 0.54^{\mathrm{a}}$ \\
\hline & $\mathrm{TP}$ & $3.21 \pm 0.44^{\mathrm{b}}$ & $0.83 \pm 0.03^{\mathrm{a}}$ & $47.28 \pm 1.46^{\mathrm{a}}$ & $10.29 \pm 0.91^{\mathrm{a}}$ & $484.15 \pm 5.52^{\mathrm{a}}$ & $32.53 \pm 2.01^{b}$ \\
\hline \multirow[t]{2}{*}{15} & WS & $7.07 \pm 2.78^{\mathrm{a}}$ & $0.08 \pm 0.00^{\mathrm{b}}$ & $4.16 \pm 0.22^{b}$ & $1.01 \pm 0.37^{\mathrm{b}}$ & $3.78 \pm 0.76^{b}$ & $75.83 \pm 2.86^{\mathrm{a}}$ \\
\hline & $\mathrm{TP}$ & $2.99 \pm 0.09^{\mathrm{a}}$ & $0.90 \pm 0.01^{\mathrm{a}}$ & $51.42 \pm 0.69^{\mathrm{a}}$ & $14.90 \pm 1.26^{\mathrm{a}}$ & $731.23 \pm 11.66^{\mathrm{a}}$ & $28.14 \pm 0.59^{b}$ \\
\hline
\end{tabular}

For each slope gradient, the value is expressed as the mean \pm the standard deviation, where the same lowercase letters indicate no significant difference.

employed by local farmers in the field. The mature wheat was harvested in June 2013. The two plot treatments comprised wheat stubble (WS) with a height of $20 \mathrm{~cm}$ above the ground, whereas the aboveground parts of the wheat biomass were cleared from the other two plots and traditional plowing was applied (TP). TP is typically used by local farmers on the sloped farmland in the Loess Plateau region. TP uses a single plow with an iron frame and an attached blade to break up and turn the soil across the slope direction at a depth of $20 \mathrm{~cm}$.

\subsection{Rainfall simulation and data analysis}

After preparing all the treatments, the plot border was hydrologically isolated with plastic boards inserted $15 \mathrm{~cm}$ underground and $15 \mathrm{~cm}$ aboveground, which prevented runoff flowing out or into adjacent plots. A 60 min rainfall simulation at an intensity of $80 \mathrm{~mm} \mathrm{~h}^{-1}$ was used in this experiment based on long-term monitoring result of the natural rainfall intensity on the Loess Plateau. After starting a rainfall simulation, the time to runoff initiation was recorded, which was determined when runoff started to flow from the outlet of the plot. Runoff samples were collected at intervals of $2.0 \mathrm{~min}$ from two plots with plastic buckets, which had been weighed previously. After finishing a rainfall simulation, the samples were weighed and left undisturbed for $24 \mathrm{~h}$. The deposited sediment was then poured into aluminum boxes, which had been weighed previously, and the sediment was oven-dried at $105^{\circ} \mathrm{C}$ for $24 \mathrm{~h}$ and then weighed again. Based on the runoff volume, sediment yield, and time interval data, the runoff rate $(\mathrm{mm} \mathrm{min}-1)$, infiltration rate $\left(\mathrm{mm} \mathrm{min}^{-1}\right)$, cumulative infil- tration amount $(\mathrm{mm})$, sediment concentration $\left(\mathrm{g} \mathrm{L}^{-1}\right)$, and sediment loss $\left(\mathrm{g} \mathrm{m}^{-2}\right)$ were calculated (Zhao et al., 2014).

One-way analysis of variance was used to analyze the effects of different treatments on the runoff rate, runoff volume, sediment concentration and loss, and the infiltration amount. Statistical analyses were performed using IBM SPSS Statistics 19.0 (IBM, 2010). The figures were drawn using Sigma Plot 10.0 (Systat, 2008).

\section{Results and discussion}

\subsection{Runoff}

Table 1 summarizes the time to runoff initiation, runoff rate, and runoff volume for different treatment plots. Figure 2 shows the dynamics of the runoff rate during the rainfall simulations. WS delayed the runoff initiation time by about 418 min compared with TP, which indicates that WS had a positive effect on runoff generation. In general, the runoff initiation time decrease in the order of WS > TP with the three slope gradients, and there was a significant difference between the two treatments $(P<0.05)$. In addition, the runoff initiation time decreased as the slope increased, as shown by Yair and Lavee (1976). However, the difference in the runoff initiation time between WS and TP decreased as the slope increased, although the difference was not significant. For example, the difference was $18.9 \mathrm{~min}$ at $5^{\circ}$ and $4.06 \mathrm{~min}$ at $15^{\circ}$. Thus, WS cover had limited effects on delaying the initiation of runoff with relatively steep slopes.

WS had a lower runoff rate and runoff volume, as shown in Table 1. There were significant differences between WS 
and TP in terms of both the runoff rate and runoff volume $(P<0.05)$. The runoff volumes were $37.86,47.28$, and $51.42 \mathrm{~mm}$ under TP with the three slopes of 5,10 , and $15^{\circ}$, respectively, but only 3.00, 3.39, and $4.16 \mathrm{~mm}$ under WS. The runoff volume under WS was reduced by $91.92-92.83 \%$ compared with that under TP. The runoff rate varied in the same manner as the runoff volume. The dynamics of the runoff rate were also captured, and the runoff processes varied greatly among treatments. In general, the runoff rate response seemed to be less sensitive to rainfall, where there was a slight increasing trend in the initial runoff stages, before remaining at low values during the rainfall simulation under WS compared with TP. Under TP, the runoff rate increased during the first 25-30 min before stabilizing after $40 \mathrm{~min}$ with all three slopes. These results demonstrate that WS direct affected the delay in runoff generation and reduced the amount of runoff. These findings are similar to the results reported by Jordán et al. (2010), who found that mulch cover significantly reduced the runoff compared with bare slope. Similarly, Puustinen et al. (2005) found that the presence of mulch facilitated infiltration and delayed runoff, thereby resulting in much less runoff. In addition, Won et al. (2012) found that straw mat cover resulted in significantly less runoff because the residues acted as a barrier to reduce the overland flow velocity, thereby allowing more rainfall to infiltrate, which minimized the runoff rate and reduced the runoff volume. Therefore, these results demonstrate that WS can significantly reduce runoff.

\subsection{Soil infiltration}

The soil water content is a limiting factor that affects crop yields in rainfed farmland in semiarid regions, especially on the Loess Plateau. Tillage during summer fallow in the Loess Plateau region aims to retain rainwater and conserve soil water moisture for the next season's crop. Precipitation is the main source of soil moisture for agronomic crops in this area, and it measures the proportion of rainwater that infiltrates into the soil, thereby providing insights into the effects of WS cover on soil water conservation.

Figure 3 shows the dynamic infiltration processes for all the treatments with various slope gradients under simulated rainfall, which indicates that there was a higher initial infiltration rate under TP, but it decreased rapidly as the simulated rainfall proceeded and reached a steady infiltration rate with small fluctuations at $25-30 \mathrm{~min}$, as observed by Wang et al. (2017). This may be explained by plowing producing a loose and rough soil surface. In the initial rainfall period, the soil particles were splashed and rainfall water was stored in micro-depressions. Therefore, the initial infiltration rate was higher and the runoff rate was lower, as shown by the results in Fig. 2 and Fig. 3. As the rainfall proceeded, the surface was sealed by the impact of raindrops, so the infiltration rate decreased rapidly (Bissonnais, 1996; Shen et al., 2016). However, the infiltration rate remained at a higher level under

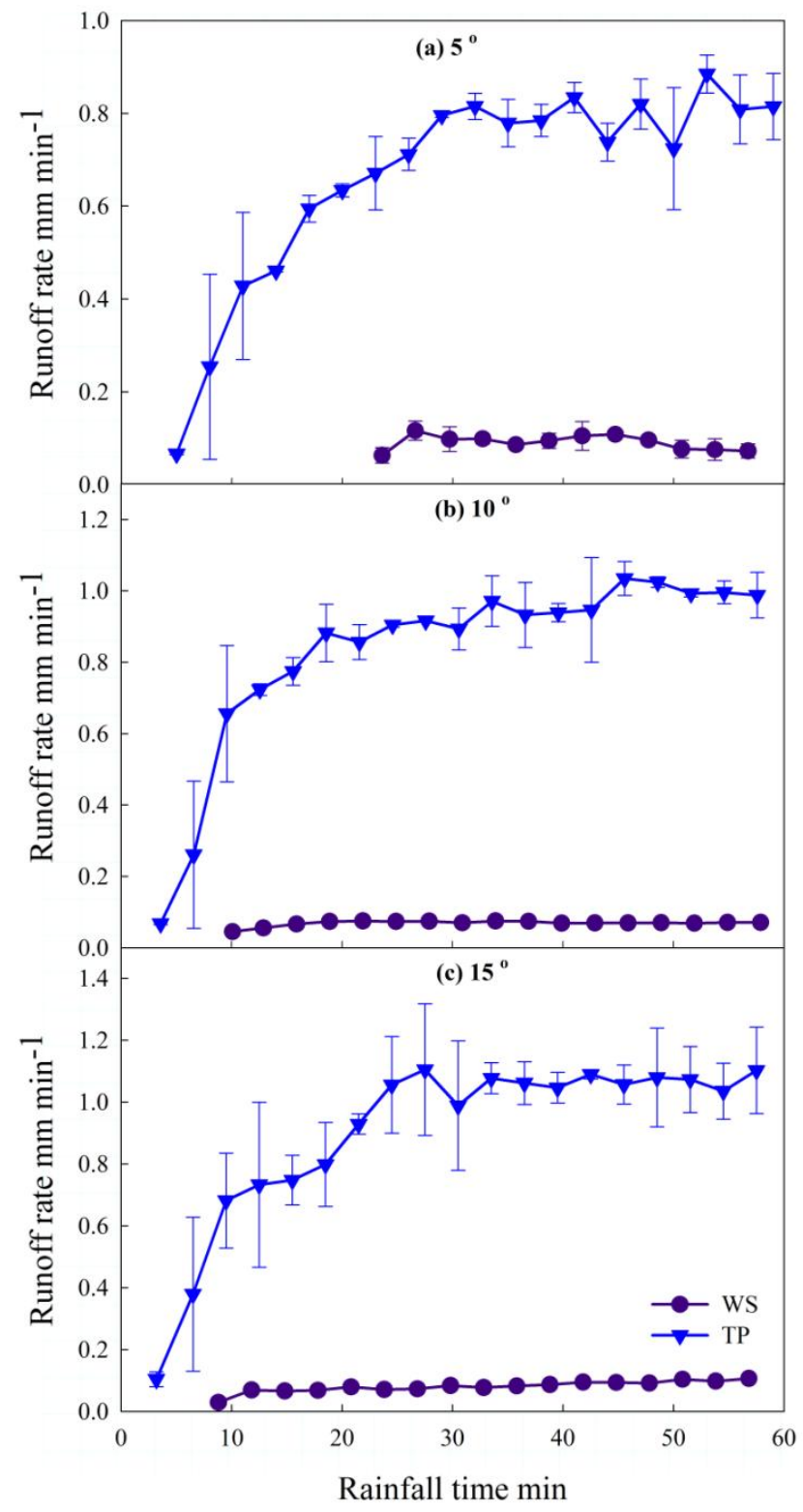

Figure 2. Dynamics of the runoff rate in WS and TP plot during the simulated rainfall event.

WS compared with TP in all of the rainfall simulation events under three slope gradients.

The cumulative infiltration amount showed that WS cover was an effective method for capturing rainfall water. Table 1 shows that the cumulative infiltration amount was significantly higher under WS than TP. The cumulative infiltration amounts under WS were $76.11\left(5^{\circ}\right), 75.95\left(10^{\circ}\right)$, and $75.83\left(15^{\circ}\right) \mathrm{mm}$ with no significant difference among different slopes, and 96.2, 95.7, and 94.8\% rainfall infiltrated into soil respectively. A similar trend was also observed under TP, where the cumulative infiltration amounts were 43.90, 32.53, and $28.14 \mathrm{~mm}$ with slopes of 5,10 , and $15^{\circ}$, respectively, i.e., $53.7,40.8$, and $35.4 \%$ rainfall infiltration. According to these 


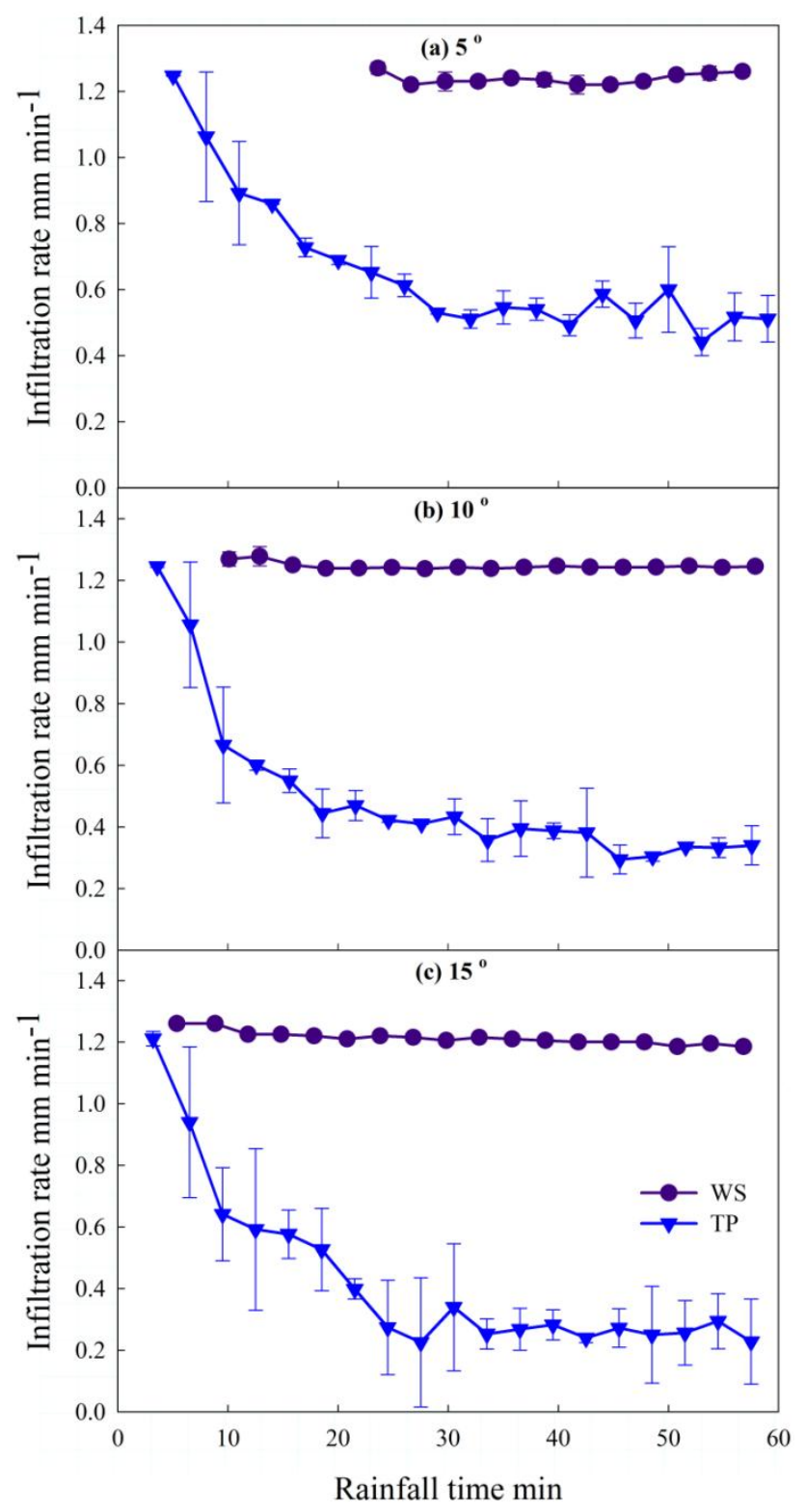

Figure 3. Dynamics of the infiltration rate in WS and TP plot during the simulated rainfall event.

results, the percentage of rainwater infiltrated indicated that WS cover significantly improved the capture of rainwater. The standing stubble at the soil-atmosphere interface protected the soil surface from the direct impact of raindrops and intercepted the rainfall near the soil surface, thereby give the rainwater more time for infiltration. This might also explain the longer time required to generate runoff, the lower runoff rates, and the higher infiltration amount under WS. Similar findings were obtained by Prosdocimi et al. (2016) using barley straw mulch in Mediterranean vineyards, Jordán et al. (2010) using wheat straw mulch under semiarid condition in southern Spain, Won et al. (2012) with straw mats covering soil in laboratory rainfall simulations, Moreno-Ramón et al. (2014) in soil mulched with coffee husks in laboratory rainfall simulations, and by Swella et al. (2015) using standing residues in a rainfed agriculture system.

\subsection{Soil loss}

Table 1 shows the sediment concentration and total sediment loss in different treatment plots. The sediment concentration under TP ranged between $8.18\left(5^{\circ}\right)$ and $14.90 \mathrm{~g} \mathrm{~L}^{-1}\left(15^{\circ}\right)$, which was significantly higher than that under WS, i.e., $0.82\left(5^{\circ}\right)-1.01 \mathrm{~g} \mathrm{~L}^{-1}\left(15^{\circ}\right)$. The total sediment loss varied in the same manner. The total sediment loss under WS was $2.41\left(5^{\circ}\right)-3.78 \mathrm{~g} \mathrm{~m}^{-2}\left(15^{\circ}\right)$, which was much lower than that under TP, i.e., $304.31\left(5^{\circ}\right)-731.23 \mathrm{~g} \mathrm{~m}^{-2}\left(15^{\circ}\right)$. The sediment loss in WS and TP was increased by $56.8 \%$ and $140.3 \%$, respectively, as the slope gradient increased from 5 to $15^{\circ}$. This indicated that wheat stubble has greater effectiveness in reducing sediment loss at a higher slope gradient. In this study, the sediment control effect of wheat stubble was supported by the infiltration capacity, leading to a significantly reduced runoff in comparison to TP despite a higher slope gradient. These results are consistent with those expected because the stubble cover decreased soil losses (Hueso-González et al., 2015). Figure 4 also shows that the dynamic changes in the sediment concentration decreased dramatically under WS compared with TP. Under TP, the sediment concentration increased rapidly in the first few minutes because runoff was generated from the loose particles on the soil surface before decreasing slightly. As the rainfall simulation progressed, the sediment concentration reached a stable state because the loose particles were exhausted. The observed changes in the sediment concentration during a rainfall event followed a typical pattern, as reported by Jordán et al. (2010), Roth and Helming (1992), and Shen et al. (2016). The differences in behavior between WS and TP may have been due to the standing stubble, which absorbed the kinetic energy of raindrops and prevented their direct splashing (Gholami et al., 2013). In addition, Jordán et al. (2010) noted that soil erosion was substantially reduced by high straw residues due to decreased runoff detachment and an increased infiltration rate. Moreover, Won et al. (2012) reported that substantial decreases in the sediment concentration under treatment with straw mat cover were due to reduced runoff, thereby minimizing the overland flow transport capacity. Furthermore, the wheat roots played an important role by reinforcing the soil and increasing infiltration (Katuwal et al., 2013; Shinohara et al., 2016), which reduced the sediment concentration and sediment losses under WS. Our results showed that TP disturbed the surface soil, which increased the available sediment source and the likelihood of soil being detached and transported by raindrops and overland flow. Ultimately, this may explain the higher sediment concentration under TP. These results agree with those obtained by Engel et al. (2009), who found that tillage disturbed the soil surface, thereby facilitating the transport of soil particles via over- 


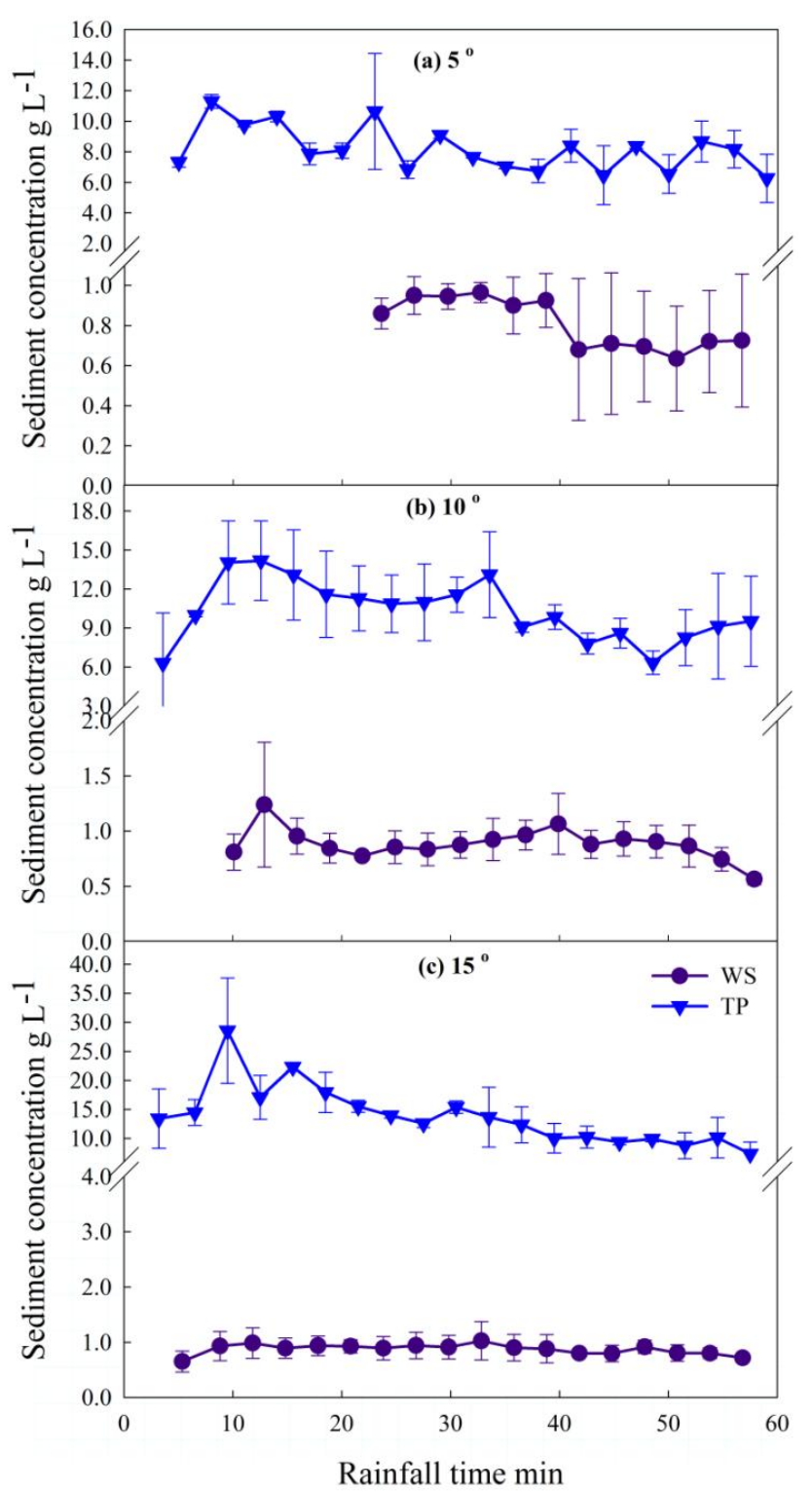

Figure 4. Dynamics of the sediment concentration in WS and TP plot during the simulated rainfall event.

land flow. Celik (2005) also concluded that disturbance by tillage could decrease the stability of soil particles, so they were more likely to be detached.

\subsection{Implications}

The Loess Plateau is highly susceptible to soil erosion because of its erodible soil, sparse vegetation cover, and concentrated summer precipitation. To address this problem, the Chinese government launched the "Grain-for-Green" project in 1999 with the aim of converting steep sloping $\left(>25^{\circ}\right)$ farmland into forest or grassland (Cao et al., 2009; Wang, 2015). However, $20 \%$ of the total farmland still has slopes of $15-25^{\circ}$ and $7 \%$ has slopes larger than $25^{\circ}$ (NDRC et al.,

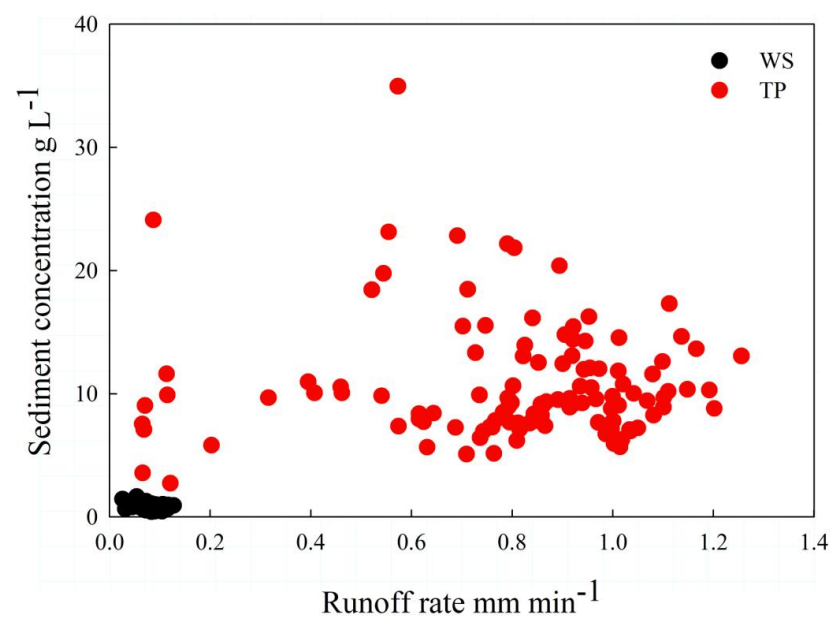

Figure 5. Runoff rates versus sediment concentrations for WS and TP management treatment.

2002). Our results confirm that WS delayed the runoff, reduced soil erosion, and increased rainwater infiltration compared with TP. Figure 5 clearly shows that WS was also effective in reducing the runoff rate and sediment concentration compared with TP. WS significantly reduced the average runoff volume from $45.52 \mathrm{~mm}$ (TP) to $3.52 \mathrm{~mm}$ (WS), and the average sediment loss from $506.56 \mathrm{~g} \mathrm{~m}^{-2}$ (TP) to $3.08 \mathrm{~g} \mathrm{~m}^{-2}$ (WS). Therefore, the runoff volume and sediment loss were reduced by 92.27 and $99.39 \%$ by the wheat stubble respectively. Therefore, these results indicate that retaining stubble at the soil-atmosphere interface can control soil erosion from farmland during the summer fallow period.

Furthermore, these experiments were conducted using small laboratory plots to test the immediate effects of stubble on runoff and soil erosion under simulated rainfall conditions. It should be noted that scale issues are important when interpreting results that affect practical applications (Sadeghi et al., 2015). However, the results obtained in the present study can be used as comparative information to indicate how WS may reduce the risk of soil erosion and increase rainwater capture on sloped farmland. Mulumba and Lal (2008) noted that the WS cover varied according to the site-specific conditions, so more studies are necessary to investigate a wider range of slopes, standing stubble height, and different plot and field scales. Furthermore, it is necessary to determine the long-term impacts of stubble cover on the soil properties (Bescansa et al., 2006; Lipiec et al., 2006), microbial activity (Song et al., 2002), soil carbon content (Amundson et al., 2015; Lal, 1993; Van et al., 2007), and soil nutrient cycling (Holland, 2004), as well as its relationships with soil erosion, crop productivity, and crop biomass utilization. These studies may provide farmers and policy makers with a comprehensive understanding of crop residue management under specific conditions in the Loess Plateau region. 


\section{Conclusions}

This study investigated the effects of WS and TP on runoff and soil erosion in laboratory plots under simulated rainfall with three different slope gradients. The results showed clearly that stubble can be used as an effective management practice during the summer fallow period in the Loess Plateau region. WS delayed the runoff initiation time and decreased the runoff rate and runoff volume. The sediment concentration and sediment losses were also decreased by WS compared with TP. In addition, WS was highly beneficial because it absorbed the kinetic energy of raindrops and promoted water infiltration. Thus, WS performed well according to all the variables considered in this study. The reductions in runoff and the sediment concentration under WS were 91.093.2 and 99.2-99.6\%, respectively, compared with TP, and infiltration was 1.69-2.45 times higher under WS than TP. In conclusion, WS was beneficial for reducing runoff and sediment losses, as well as increasing infiltration under simulated rainfall. Stubble cover can be adopted as a management practice by farmers to control soil erosion and promote rainwater conservation in the summer fallow period. Future studies should evaluate the performance of this crop biomass by-product in diverse field conditions.

Data availability. The data of this article can be found in the Supplement.

\section{The Supplement related to this article is available online at doi:10.5194/se-8-281-2017-supplement.}

Competing interests. The authors declare that they have no conflict of interest.

Acknowledgements. This study was financially supported by the National Natural Science Foundation of China (41271288). The authors gratefully thank Duncan E. Jackson for editing and improving the manuscript.

Edited by: M. Oliva

Reviewed by: two anonymous referees

\section{References}

Aboudrare, A., Debaeke, P., Bouaziz, A., and Chekli, H.: Effects of soil tillage and fallow management on soil water storage and sunflower production in a semi-arid Mediterranean climate, Agr. Water Manage., 83, 183-196, 2006.

Adekalu, K. O., Olorunfemi, I. A., and Osunbitan, J. A.: Grass mulching effect on infiltration, surface runoff and soil loss of three agricultural soils in Nigeria, Bioresource Technology, 98, 912-917, 2007.
Amundson, R., Berhe, A. A., Hopmans, J. W., Olson, C., Sztein, A. E., and Sparks, D. L.: Soil and human security in the 21 st century, Science, 348, 1261071-6, doi:10.1126/science.1261071, 2015.

Bescansa, P., Imaz, M. J., Virto, I., Enrique, A., and Hoogmoed, W. B.: Soil water retention as affected by tillage and residue management in semiarid Spain, Soil and Tillage Research, 87, 19-27, 2006.

Bissonnais, Y. L.: Aggregate stability and assessment of soil crustability and erodibility: I. theory and methodology, European Journal of Soil Science, 47, 425-437, 1996.

Blanco, H. and Lal, R.: Principles of soil conservation and management, Springer, 167-169, 2008.

Boardman, J., Foster, I. D. L., and Dearing, J. A.: Soil Erosion on Agricultural Land, John Wiley and Sons, Chichester, 1990.

Cao, S., Chen, L., and Yu, X.: Impact of China's Grain for Green Project on the landscape of vulnerable arid and semi-arid agricultural regions: a case study in northern Shaanxi Province, J. Appl. Ecol., 46, 536-543, 2009.

Celik, I.: Land-use effects on organic matter and physical properties of soil in a southern Mediterranean highland of Turkey, Soil and Tillage Research, 83, 270-277, 2005.

Cerdà, A., Morera, A. G., and Bodí, M. B.: Soil and water losses from new citrus orchards growing on sloped soils in the western Mediterranean basin, Earth Surf. Proc. Landf., 34, 1822-1830, 2009.

Cerdà, A., González-Pelayo, Ó., Giménez-Morera, A., Jordán, A., Pereira, P., Novara, A., Brevik, E.C., Prosdocimi, M., Mahmoodabadi, M., Keesstra, S., Orenes, F. G., and Ritsema, C. J.: Use of barley straw residues to avoid high erosion and runoff rates on persimmon plantations in Eastern Spain under low frequencyhigh magnitude simulated rainfall events, Soil Research, 54, 154-165, 2016.

Engel, F. L., Bertol, I., Ritter, S. R., Paz González, A., Paz-Ferreiro, J., and Vidal Vázquez, E.: Soil erosion under simulated rainfall in relation to phenological stages of soybeans and tillage methods in Lages, SC, Brazil, Soil and Tillage Research, 103, 216-221, 2009.

Gholami, L., Sadeghi, S. H., and Homaee, M.: Straw mulching effect on splash erosion, runoff, and sediment yield from eroded plots, Soil Sci. Soc. Am. J., 77, 268-278, 2013.

Gholami, L., Banasik, K., Sadeghi, S. H., Khaledi Darvishan, A., and Hejduk, L.: Effectiveness of straw mulch on infiltration, splash erosion, runoff and sediment in laboratory conditions, J. Water Land Develop., 22, 51-60, 2014.

Gómez, J. A., Romero, P., Giráldez, J. V., and Fereres, E.: Experimental assessment of runoff and soil erosion in an olive grove on a Vertic soil in southern Spain as affected by soil management, Soil Use Manage., 20, 426-431, 2004.

Hammel, J. E., Papendick, R. I., and Campbell, G. S.: Fallow tillage effects on evaporation and seedzone water content in a dry summer climate, Soil Sci. Soc. Am. J., 45, 1010-1022, 1981.

Holland, J. M.: The environmental consequences of adopting conservation tillage in Europe: reviewing the evidence, Agr. Ecosyst Environ., 103, 1-25, 2004.

Huang, J., Wu, P., and Zhao, X.: Effects of rainfall intensity, underlying surface and slope gradient on soil infiltration under simulated rainfall experiments, Catena, 104, 93-102, 2013.

Hueso-González, P., Ruiz-Sinoga, J. D., Martínez-Murillo, J. F., and Lavee, H.: Overland flow generation mechanisms affected 
by topsoil treatment: Application to soil conservation, Geomorphology, 228, 796-804, 2015.

IBMC: IBM SPSS Statistics for Windows, Version 19.0, IBM Corporation, Armonk, NY, 2010.

Jordán, A., Zavala, L. M., and Gil, J.: Effects of mulching on soil physical properties and runoff under semi-arid conditions in southern Spain, Catena, 81, 77-85, 2010.

Katuwal, S., Vermang, J., Cornelis, W. M., Gabriels, D., Moldrup, P., and de Jonge, L. W.: Effect of root density on erosion and erodibility of a loamy soil under simulated rain, Soil Sci., 178, 29-36, 2013.

Keesstra, S., Pereira, P., Novara, A., Brevik, E. C., Azorin-Molina, C., Parras-Alcantara, L., Jordan, A., and Cerdà, A.: Effects of soil management techniques on soil water erosion in apricot orchards, Sci. Total Environ., 551-552, 357-366, 2016.

Kukal, S. and Sarkar, M.: Splash erosion and infiltration in relation to mulching and polyvinyl alcohol application in semi-arid tropic, Archives of Agronomy and Soil Science, 56, 697-705, 2010.

Lal, R.: Tillage effects on soil degradation, soil resilience, soil quality, and sustainability, Soil and Tillage Research, 27, 1-8, 1993.

Lee, H. and Yang, Y.: Effect of summer plowing on the winter wheat, Acta Pedologica Sinica, 13, 405-411, 1965 (in Chinese with English abstract).

Lipiec, J., Kuś, J., Słowińska-Jurkiewicz, A., and Nosalewicz, A.: Soil porosity and water infiltration as influenced by tillage methods, Soil and Tillage Research, 89, 210-220, 2006.

Liu, Y., Fu, B., Lü, Y., Wang, Z., and Gao, G.: Hydrological responses and soil erosion potential of abandoned cropland in the Loess Plateau, China, Geomorphology, 138, 404-414, 2012.

Llorens, P. and Domingo, F.: Rainfall partitioning by vegetation under Mediterranean conditions. A review of studies in Europe, J. Hydrol., 335, 37-54, 2007.

Moreno-Ramón, H., Quizembe, S. J., and Ibáñez-Asensio, S.: Coffee husk mulch on soil erosion and runoff: experiences under rainfall simulation experiment, Solid Earth, 5, 851-862, doi:10.5194/se-5-851-2014, 2014.

Mulumba, L. and Lal, R.: Mulching effects on selected soil physical properties, Soil and Tillage Research, 98, 106-111, 2008.

Mwango, S. B., Msanya, B. M., Mtakwa, P. W., Kimaro, D. N., Deckers, J., and Poesen, J.: Effectiveness of mulching under Mirabain controlling soil erosion, fertility restoration and crop yield in the Usambara Mountains, Tanzania, Land Degrad. Develop., 27, 1266-1275, 2016.

NDRC (National Development and Reform Commission), MWR (Ministry of Water Resources of China), MOA (Ministry of Agriculture of China), SFA (State Forestry Administration of China), Outline of integrated management on the Loess Plateau from 2010 to 2030, 2002.

Nishigaki, T., Shibata, M., Sugihara, S., Mvondo-Ze, A. D., Araki, S., and Funakawa, S.: Effect of mulching with vegetative residues on soil water erosion and water balance in an Oxisol cropped by cassava in east Cameroon, Land Degrad. Develop., 28, 682-690, 2017a.

Nishigaki, T., Sugihara, S., Kilasara, M., and Funakawa, S.: Surface runoff generation and soil loss under different soil and rainfall properties in the Uluguru Mountains, Tanzania, Land Degrad. Develop., 28, 283-293, 2017 b.
Prosdocimi, M., Jordán, A., Tarolli, P., Keesstra, S., Novara, A., and Cerdà, A.: The immediate effectiveness of barley straw mulch in reducing soil erodibility and surface runoff generation in Mediterranean Vineyards, Sci. Total Environ., 547, 323-330, 2016.

Puustinen, M., Koskiaho, J., and Peltonen, K.: Influence of cultivation methods on suspended solids and phosphorus concentrations in surface runoff on clayey sloped fields in boreal climate, Agr. Ecosyst. Environ., 105, 565-579, 2005.

Roth, C. and Helming, K.: Dynamics of surface sealing, runoff formation and interrill soil loss as related to rainfall intensity, microrelief and slope, J. Plant Nutr. Soil Sci., 155, 209-216, 1992.

Sadeghi, S. H. R., Gholami, L., Sharifi, E., Khaledi Darvishan, A., and Homaee, M.: Scale effect on runoff and soil loss control using rice straw mulch under laboratory conditions, Solid Earth, 6, 1-8, doi:10.5194/se-6-1-2015, 2015.

Shen, H., Zheng, F., Wen, L., Han, Y., and Hu, W.: Impacts of rainfall intensity and slope gradient on rill erosion processes at loessial hillslope, Soil and Tillage Research, 155, 429-436, 2016.

Shi, H. and Shao, M.: Soil and water loss from the Loess Plateau in China, J. Arid Environ., 45, 9-20, 2000.

Shinohara, Y., Otani, S., Kubota, T., Otsuki, K., and Nanko, K.: Effects of plant roots on the soil erosion rate under simulated rainfall with high kinetic energy, Hydrol. Sci. J., 61, 2435-2442, 2016.

Song, R., Wu, C., Mou, J., Jiang, Y., and Guo, J.: Effects of maize stubble remaining in field on dynamics of soil microbial biomass C and soil enzyme activities, Chinese J. Appl. Ecol., 13, 303306, 2002 (in Chinese with English abstract).

Strudley, M., Green, T., and Ascoughii, J.: Tillage effects on soil hydraulic properties in space and time: State of the science, Soil and Tillage Research, 99, 4-48, 2008.

Swella, G. B., Ward, P. R., Siddique, K. H. M., and Flower, K. C.: Combinations of tall standing and horizontal residue affect soil water dynamics in rainfed conservation agriculture systems, Soil and Tillage Research, 147, 30-38, 2015.

Systat: Sigma Plot, Version 10.0, Systat Software Inc., San Jose, CA, 2008.

Tang, K.: Soil and water conservation in China, Chinese Science Press: Beijing, 15-20, 2004 (in Chinese).

Todd, R. W., Klocke, N. L., Hergert, G. W., and Parkhurst, A. M.: Evaporation from soil influenced by crop shading, crop residue, and wetting regime, Trans. of ASAE, 34, 461-466, 1991.

Van, K. O., Quine, T. A., Govers, G., Gryze, S. D., Six, J., Harden, J. W., Ritchie, J. C., McCarty, G. W., Heckrath, G., Kosmas, C., Giraldez, J. V., da Silva, J. R. M., and Merckx, R.: The impact of agricultural soil erosion on the global carbon cycle, Science, 318, 626-629, 2007.

Vermang, J., Norton, L. D., Huang, C., Cornelis, W. M., da Silva, A. M., and Gabriels, D.: Characterization of soil surface roughness effects on runoff and soil erosion rates under simulated rainfall, Soil Sci. Soc. Am. J., 79, 903-916, 2015.

Wang, J., Huang, J., Zhao, X., Wu, P., Horwath, W. R., Li, H., Jing, Z., and Chen, X.: Simulated study on effects of ground managements on soil water and available nutrients in jujube orchards, Land Degrad. Develop., 27, 35-42, 2016.

Wang, L., Dalabay, N., Lu, P., and Wu, F.: Effects of tillage practices and slope on runoff and erosion of soil from the Loess Plateau, 
China, subjected to simulated rainfall, Soil and Tillage Research, 166, 147-156, 2017.

Wang, T.: Soil Erosion is influenced by Grain for Green Policy in Loess Plateau Area of Northern Shaanxi, China, International Journal of Environmental Protection and Policy, 3, 129-136, 2015.

Won, C. H., Choi, Y. H., Shin, M. H., Lim, K. J., and Choi, J. D.: Effects of rice straw mats on runoff and sediment discharge in a laboratory rainfall simulation, Geoderma, 189-190, 164-169, 2012.

Wu, Q., Wang, L., and Wu, F.: Tillage - impact on infiltration of the Loess Plateau of China, Acta Agriculturae Scandinavica Section B-Soil and Plant Science, 64, 341-349, 2014.

Yair, A. and Lavee, H.: Runoff generative process and runoff yield from arid talus mantled slopes, Earth Surf. Proc., 1, 235-247, 1976.
Zhao, G., Mu, X., Jiao, J., An, Z., Klik, A., Fei, W., Jiao, F., Yue, X., Gao, P., and Sun, W.: Evidence and causes of spatiotemporal changes in runoff and sediment yield on the chinese loess plateau, Land Degrad. Develop., 28, 579-590, 2017.

Zhao, L., Wang, L., Liang, X., Wang, J., and Wu, F.: Soil surface roughness effects on infiltration process of a cultivated slopes on the Loess Plateau of China, Water Resour. Manage., 27, 47594771, 2013.

Zhao, X., Huang, J., Wu, P., and Gao, X.: The dynamic effects of pastures and crop on runoff and sediments reduction at loess slopes under simulated rainfall conditions, Catena, 119, 1-7, 2014.

Ziadat, F. M. and Taimeh, A. Y.: Effect of Rainfall Intensity, Slope, Land Use and Antecedent Soil Moisture on Soil Erosion in an Arid Environment, Land Degrad. Develop., 24, 582-590, 2013. 